\title{
LOUVAIN NATURAL RADIOCARBON MEASUREMENTS IX
}

\section{E. GILOT}

Department of Nuclear Chemistry, University of Louvain, Louvain, Belgium

The $\mathrm{C}^{14}$ dates given below have been obtained by counting $\mathrm{CH}_{4}$ at $3 \mathrm{~atm}$ pressure in a $0.6 \mathrm{~L}$ stainless steel counter. Details of procedure are given in the previous lists. Dates are reported in terms of the Libby half-life, $5570 \pm 30$ years; the errors quoted are based on the standard deviations in counting rate of samples and standards. mitters.

The descriptions and comments are essentially those of the sub-

\section{ACKNOWLEDGMENTS}

Thanks are due P. Capron for his constant guidance, F. Frix for routine sample preparation, and G. Michotte for electronics maintenance. Financial support is provided by the Fonds de la Recherche Fondamentale Collective, Brussels.

\section{SAMPLE DESGRIPTIONS}

\section{Sedentarization series, France}

Samples from various localities from France subm. by M. Coûteaux, Lab. of Palynology, Univ. of Louvain, now at Research Center of Ecology and Prehistory, Saint André de Cruzières, Ardèche, France. Samples related to palynologic research on archaeol. sites, for the "Recherche coopérative sur Programme no. 78: La Sédentarisation (CNRS)."

General Comment: samples leached with $\mathrm{HCl}$ but not with $\mathrm{NaOH}$; the possible, but not probable, humic contamination is not removed.

\section{Lv-384. Malaroumet II a}

$1290 \pm 80$

Peat from Malaroumet ( $44^{\circ} 59^{\prime} \mathrm{N}$ Lat, $0^{\circ} 19^{\prime} \mathrm{E}$ Long) at Baleymas, Dept. of Dordogne, alt $120 \mathrm{~m}$. From 501 to $511 \mathrm{~cm}$ below ground surface. Coll. 1968 and pollen analyzed by M. Coûteaux. Comment: pollen diagram shows at this level a maximum of Carpinus (Coûteaux, 1970). Date comparable with $\mathrm{C}^{14}$ dates from Belgium, where this maximum is generally dated ca. A.D. 700 .

\section{Lv-385. Malaroumet II b}

$1620 \pm 60$

Peat from 513 to $519 \mathrm{~cm}$ depth. Comment: pollen curves show an increase of Carpinus during a maximum of Fagus and Quercus. Date seems a little too old compared to Lv-386 and Lv-387, but confirms that the increase of Fagus in Aquitaine belongs to Sub-Atlantic period. 


\section{Lv-386. Malaroumet II c}

$1510 \pm 90$

Wood from 520 to $525 \mathrm{~cm}$ depth. Comment: pollen analysis shows a temporary increase of Corylus between 2 maxima of Fagus. Later than the lst maximum of Fagus, confirms the Lv-387 date.

\section{Lv-387. Malaroumet II d}

$1570 \pm 80$

Peat from 526 to $536 \mathrm{~cm}$. Comment: dates the 1 st maximum of Fagus lower than Quercus before increase of Carpinus. Date comparable to $\mathrm{F} 1$ in Belgium. Some hypotheses implied an earlier increase of Fagus in Aquitaine (Paquereau, 1960).

\section{Lv-388. Gaude}

$4060 \pm 80$

Charcoal with sand from the Gaude cave $\left(44^{\circ} 36^{\prime} \mathrm{N}\right.$ Lat, $4^{\circ}$ в.c. Long) at Saint Etienne de Fonbellon, Dept. of Ardèche, alt $250 \mathrm{~m}$. From Sq. 8 of the Nikitine excavating, at $8 \mathrm{~m}$ from upper inlet of cave, archaeolog. level 28 to $42 \mathrm{~cm}$ below ground surface. At this level, Chalcolithic industry. Coll. 1966 by S. Nikitine. Comment: archaeol. estimation between 2200 and 2000 B.c. $\mathrm{C}^{1+}$ date confirms estimation and helps to place on the time-scale a pollen diagram which cannot be palynologically dated because there is no pollen diagram reference yet in Arclèche.

\section{Lv-389. Francin I}

$3870 \pm 170$

N Lat, $6^{\circ} 01^{\prime}$ Eow $)$, from Francin $\left(45^{\circ}-30^{\prime}\right.$ depth. In the sediment, a rich Chassean industry 288 . Horizon 4 at $90 \mathrm{~cm}$ Coll. 1967 by M. Malenfant. Comment: sample too poor to be treated in normal conditions is measured at $1000 \mathrm{~mm} \mathrm{Hg}$ pressure. Date seems $500 \mathrm{yr}$ too young in comparison with archaeol. estimation, probably because of large scattering of sample.

\section{Lv-390. Francin 3}

$4300 \pm 75$

Charcoal from $\mathrm{S}_{\mathrm{Y}} 4$, from a built hearth in Chassean in Coll 1967 by Malenfont Comment: Cit tion (ca. 2400 B. ) and helps to chte and farming in the site.

\section{Lv-391. Gare de Couze}

$10,900 \pm 230$

Bone collagen (principally Rangifer tarandus) (Prat, 1962), from Couze $\left(44^{\circ} 50^{\prime} \mathrm{N}\right.$ Lat, $0^{\circ} 82^{\prime} \mathrm{E}$ Long) at Lalinde, Dept. of Dordogne, alt $40 \mathrm{~m}$. Found at 20 to $40 \mathrm{~cm}$ below present ground surface, in the Magdalenian VI archaeol. level, said "level 2, grey-blackish principal archaeol. layer" (Fitte and Sonneville-Bordes, 1962), including the strat. Horizons B to G (Laville, 1964). Coll. 1965 by J. Guichard and M. 
Coûteaux. Comment: bones are dissolved in cold HCl. IN and collagen heated to $250^{\circ} \mathrm{C}$ before combustion. Date is averaged from 2 dates: 10,993 and 10,782 в.P. $C^{14}$ date places to Alleröd-Recent Dryas transition a temperate-cold pollen sequence characterized by the sporadic occurrence of a few thermophile plants. Without local pollen diagram reference, it is not possible to check this chronologic position; nevertheless, the observed vegetation seems to exclude Alleröd and Pre-Boreal periods. From archaeol. results, an older age (500 to $1000 \mathrm{yr}$, according to Bordes) is expected, because the industry is certainly evolved but not final.

\section{Lv-395. Chazelle, Layer VII}

$5660 \pm 110$

Ash from Chazelle $\left(44^{\circ} 18^{\prime} \mathrm{N}\right.$ Lat, $4^{\circ} 11^{\prime} \mathrm{E}$ Long) at Saint André de Cruzières, Dept. of Ardèche, alt $200 \mathrm{~m}$. Layer VII of the Nikitine excavation. Neolithic hearth related to Cardial pottery from Montalus (Gard). Coll. 1967 by S. Nikitine. Comment: dates a pollen phase from Chazelle cave. At this level, forest component is still small on the plant scenery $(30 \%$ trees, principally Quercus); human influence is very marked: plantago up to $6 \%$, grain up to $8 \%$, but vine is not yet observed. $\mathrm{C}^{14}$ clate is not in contradiction with the 1st archaeol. estimation, but a total discussion will be possible only after complete study of the excavated material by Nikitine.

\section{Lv-396. Chazelle, Layer IV}

$3240 \pm 120$ 1290 B.c.

Charcoal from Layer IV of the Nikitine excavation in Chazelle cave. Archaeol. level attributed to Middle Bronze age. Comment: pollen diagram shows a treeless phase, where human influence is marked (Plantago) but grain is very rare and vine discontinuous. Date is too young according to the 1st archaeol. estimation; the results of complete study by Nikitine are expected.

\section{Oetrange series, Luxembourg}

Samples from Haed Plateau at Oetrange $\left(49^{\circ} 35^{\prime} 45^{\prime \prime}\right.$ N Lat, $6^{\circ} 14^{\prime}$ $30^{\prime \prime}$ E Long), Luxembourg. The plateau, Hettangien sandstone, is flanked by 2 valleys in which samples were found. Coll. 1932 to 1939 by N. Thill; subm. by M. Heuertz, Nat. Hist. Mus. of Luxembourg.

\section{Lv-466. Oetrange 1}

$16,070 \pm 450$

14,120 в.C.

Horns of reindeer from sandy, stony and calcareous ground ca. $1 \mathrm{~m}$ thick, slipped down at foot of perpendicular rocks in Schlaederbâch Valley, SW of the Plateau.

\section{Lv-467. Oetrange 2}

$16,770 \pm 390$

Bones, principally horse, from filled joint in the Kakesbach valley, NE of the Plateau. 
General Comment: dates on collagen extracted by sample dissolution in cold $\mathrm{HCl}-\mathrm{lN}$; NaOH-leach omitted. Fauna of Oetrange sites is characteristic of Middle and Upper Pleistocene (Ferrant et al., 1942). The prehistoric industry is attributed to Upper Pleistocene (Ferrant and Thill, 1938; Baudet et al., 1953). $\mathrm{C}^{14}$ dates confirm expectation and give minimum date of creation of joint.

\section{Mios series, France}

Samples from Mios, Dept. of Gironde, France. Coll. 1910 by B. Peyneau; subm. by J. P. Mohen, Aquitaine Mus., Bordeaux.

\section{Lv-351. Tumulus de Pujaut}

$$
420 \pm 85
$$

Charcoal from Tumulus $\mathrm{G}$ at Pujaut $\left(44^{\circ} 35^{\prime} \mathrm{N}\right.$ Lat, $0^{\circ} 57^{\prime} \mathrm{W}$ Long). Comment: $\mathrm{C}^{14}$ age is averaged from 2 dates: 414 and 423 yr. Date absolutely inconsistent with furniture of tumulus. Probably charcoal from a woodcutter fire.

\section{Lv-352. True du Bourdiou}

Charred acorns from Truc du Bourdiou $\left(44^{\circ} 35^{\prime} \mathrm{N}\right.$ Lat, $0^{\circ} 55^{\prime} \mathrm{W}$ Long). From Pit K at $50 \mathrm{~cm}$ depth under an urn-field (Peyneau, 1926). Comment: urn-field is late classical of 1st Iron age in Aquitaine, but potsherds found in the pits filled by charred acorns seem older and not related to 1st Iron age necropolis (Coffyn and Mohen, 1969). $\mathrm{C}^{14}$ date agrees with Last Atlantic Bronze age.

\section{Elkab series, Egypt}

Charcoal from Elkab (25 $08^{\prime} \mathrm{N}$ Lat, $32^{\circ} 47^{\prime}$ E Long), Prov. of Edfu, Egypt. From an Epipaleolithic hearth found in Nile R. sediments. Coll. 1968 and 1969 and subm. by P. Vermeersch, Univ. of Louvain, Lab. of Phys. Geog.

\section{Lv-464. Elkab}

$7990 \pm 150$

From lower layer, 70 to $80 \mathrm{~cm}$ below ground surface.

\section{Lv-465. Elkab}

From upper layer, 30 to $50 \mathrm{~cm}$ depth.

$7930 \pm 160$

5980 в.c.

General Comment: not leached with $\mathrm{NaOH}$. Confirms date 6400 B.c. for Lv-393 (Radiocarbon, 1970, v. 12, p. 157). They are the 1st dates of prehistoric industry in Egypt between 9000 B.c. and 4600 B.c.

\section{Lv-443. Etang de Lierneux}

$320 \pm 70$

Oak wood from Lierneux $\left(50^{\circ} 20^{\prime} \mathrm{N}\right.$ Lat, $5^{\circ} 48^{\prime} \mathrm{E}$ Long), Prov. of Liege, Belgium. From emptying duct of a pond, at ca. $5 \mathrm{~m}$ depth under clayey schistous embankment. Coll. 1965 and subm. by J. Humblet, 
Univ. of Liege. Comment: dates building of pond by monastery nearby (now Noire-fontaine farm-house) amenable to Abbey of Stavelot.

\section{Basse Meuse series}

Wood samples from former channels of Meuse R. in Prov. of Limburg, Belgium. Coll. 1967 and 1968 and subm. by E. Paulissen, Univ. of Louvain, Lab. of Phys. Geog.

General Comment: this series dates lateral shifting of Meuse R. channel and shows that river transported gravel during the Holocene (Paulissen, 1970).

Lv-435. Leut, B 2

$7060 \pm 150$

5110 B.c.

From Leut ( $50^{\circ} 59^{\prime} 23^{\prime \prime} \mathrm{N}$ Lat, $5^{\circ} 43^{\prime} 52^{\prime \prime}$ E Long), alt $32 \mathrm{~m}$. Overlain by $4 \mathrm{~m}$ alluvium.

\section{Lv-436. Geistingen, $B$}

$5080 \pm 120$

From Geistingen (51 $08^{\prime} 13^{\prime \prime} \mathrm{N}$ Lat, $5^{\circ} 49^{\prime} 47^{\prime \prime} \mathrm{E}$ Long), alt $27 \mathrm{~m}$. Overlain by $4 \mathrm{~m}$ alluvium.

\section{Lv-439. Geistingen, B 6}

$1550 \pm 70$

From $450 \mathrm{~m}$ E from Lv-436, depth $5 \mathrm{~m}$, in a gravel layer overlain by $1 \mathrm{~m}$ sandy clay.

\section{Lv-438. Geistingen, B 5}

$1130 \pm 75$

From $110 \mathrm{~m} \mathrm{SW}$ from $\mathrm{Lv}-439$, under $5 \mathrm{~m}$ alluvium.

Lv-437. Boorsem, B 4

From Boorsem (50 $56^{\prime} 46^{\prime \prime} \mathrm{N}$ Lat, $5^{\circ} 42^{\prime} 53^{\prime \prime} \mathrm{E}$ Long), alt $43 \mathrm{~m}$, depth $2.70 \mathrm{~m}$, in gravel overlain by $1.20 \mathrm{~m}$ alluvium.

Lv-440. Kessenich, B 7

From Kessenich (51 $08^{\prime} 47^{\prime \prime} \mathrm{N}$ Lat, 5० 50' 56" E Long), alt $27 \mathrm{~m}$, under $4 \mathrm{~m}$ alluvium.

\section{Lv-441. Aldeneik, B 8}

$1050 \pm 75$

From Aldeneik (51 $06^{\prime} 10^{\prime \prime} \mathrm{N}$ Lat, $5^{\circ} 49^{\prime} 27^{\prime \prime} \mathrm{E}$ Long), alt $29 \mathrm{~m}$, depth $4 \mathrm{~m}$. From alluvial gravel depth $2 \mathrm{~m}$.

\section{REFERENCES}

Baudet, J. L., Heuertz, M., and Schneider, E., 1953, La préhistoire du Grand-Duché de Luxembourg: Soc. d'Anthropol. Paris Bull. et Mem., t. 4, ser. X.

Coffyn, A. and Mohen, J. P., 1969, Les nécropoles Hallstattiennes de la région d'Arcachon: Madrid, Bibliotheca Praehistorica Hispana, v. 11.

Coûteaux, M., 1970, Origine et extension post-glaciaire du hêtre (Fagus sylvatica) dans le Bassin d'Aquitaine (France), Note prélim.: Acad. sci. [Paris] Comptes rendus, t. 270 , p. 690-693.

Ferrant, V., Friant, M., and Thill, N., 1942, La faune pléistocene d'Oetrange (Grand Duché de Luxembourg), Résumé et conclusions, L'âge du gisement: Paris,
Anthropol. Rev., 15 p. 
Ferrant, V. and Thill, N., 1938, Industric de la station préhistorique d'Oetrange (Grand Duché de Luxembourg): Soc. Naturalistes Luxembourgeois Bull., 1938.

Fitte, P and de Sonneville-Bordes, D., 1962, Le Magdalénien VI de la Gare de Couze, Commune de Lalinde (Dordogne): Anthropologie, v. 66, p. 217-246.

Gilot, E., 1970, Louvain natural radiocarbon measurements VIII: Radiocarbon, v. 12 , p. $156-160$.

Laville, H., 1964, Recherches sédimentologiques sur la paléoclimatologie du Wurmien récent au Périgord: Anthropologie, v. 68, p. 1-48, 219-252.

Malenfant, M., Coûteaux, M., and Cauvin, J., 1970, Le gisement Chasséen de Francin (Savoie): Gallia Préhistoire, in press.

Paquereau, M. M., 1960, Tourbes et forêt fossile du littoral de Lacanau-Océan (Gironde): Soc. Géol. France Comptes rendus, no. 6, p. 143-144.

Paulissen, E., 1970, De Maasvallei in Belgisch Limburg, Een morfologische en Kwartairstratigrafische studie: Ph.D. thesis, Univ. Louvain.

Peyneau, B., 1926, Découvertes archéologiques dans le pays de Buch: Bordeaux, v. 1. Prat, F., 1962, La faune du gisement de la Gare de Couze: Anthropologie, v. 66, p. $247-254$. 